\title{
VEHICLE AIR CONDITIONER (VAC) CONTROL SYSTEM BASED ON PASSENGER COMFORT: A PROOF OF CONCEPT
}

\author{
Suroto Munahar ${ }^{1}$, Bagiyo CONDro Purnomo ${ }^{1}$, Muhammad IZzudin ${ }^{1}$, \\ MUJI SETIYO $^{1^{*}}$ AND MADIHAH MOHD SAUDI ${ }^{2}$ \\ ${ }^{1}$ Department of Automotive Engineering, Universitas Muhammadiyah Magelang, \\ Magelang 56172, Indonesia \\ ${ }^{2}$ Faculty of Science and Technology, Universiti Sains Islam Malaysia, \\ Bandar Baru Nilai 71800, Nilai, Negeri Sembilan, Malaysia \\ "Corresponding author: muji@unimma.ac.id
}

(Received: 28 $8^{\text {th }}$ January 2021; Accepted: $5^{\text {th }}$ April 2021; Published on-line: $4^{\text {th }}$ January 2022)

\begin{abstract}
The air conditioning system (AC) in passenger cars requires precise control to provide a comfortable and healthy driving. In an AC system with limited manual control, the driver has to repeatedly change the setting to improve comfort. This problem may be overcome by implementing an automatic control system to maintain cabin temperature and humidity to meet passenger's thermal comfort. Therefore, this paper presents the development of a laboratory-scale prototype air conditioning control system to regulate temperature, humidity and air circulation in the cabin. The experimental results show that the control system is able to control air temperature in the range of $21^{\circ} \mathrm{C}$ to 23 ${ }^{\circ} \mathrm{C}$ and cabin air humidity between $40 \%$ to $60 \%$ in various simulated environmental conditions which indicate acceptance for comfort and health standards in the vehicle. In conclusion, this method can be applied to older vehicles with reasonable modifications.
\end{abstract}

ABSTRAK: Sistem penyejuk udara (AC) pada kenderaan penumpang memerlukan ketepatan kawalan bagi menyediakan keselesaan dan kesejahteraan pemanduan. Melalui sistem AC dengan kawalan manual terhad, pemandu perlu berulang kali mengubah penyesuaian latar bagi meningkatkan keselesaan. Masalah ini dapat diatasi dengan menerapkan sistem kawalan automatik bagi menjaga suhu dan kelembapan kabin agar memenuhi keselesaan suhu penumpang. Oleh itu, kajian ini merupakan pembangunan prototaip sistem kawalan AC skala laboratari bagi mengawal suhu, kelembapan dan peredaran udara dalam kabin. Hasil eksperimen menunjukkan sistem kawalan ini mampu mengendali suhu udara pada kitaran $21{ }^{\circ} \mathrm{C}$ hingga $23{ }^{\circ} \mathrm{C}$ dan kelembaban udara kabin antara $40 \%$ hingga $60 \%$ pada pelbagai keadaan persekitaran simulasi yang menunjukkan penerimaan standard keselesaan dan kesejahteraan kenderaan. Sebagai kesimpulan, cara ini dapat diaplikasi pada kenderaan lama dengan modifikasi bersesuaian.

KEYWORDS: air conditioner; control system; humidity; temperature

\section{INTRODUCTION}

The vehicle air conditioner (AC) system was developed to provide passenger comfort. Initially, the AC system was only used to regulate temperature but that is not enough anymore. Although the thermal comfort of building occupants has been studied extensively, in-vehicle thermal comfort is continuously being developed due to its dynamics. Since vehicles operate in a dynamic environment, therefore passenger comfort in the vehicle is very important to ensure people travel safely [1-3]. Moreover, as climate change causes 
temperature extremes, a study proposes to formulate new guidelines for car design based on passengers' thermal comfort to avoid health impacts [4].

Apart from temperature, to provide passenger comfort in the targeted cabin, humidity and air circulation speed are also important parts that must be considered [5,6]. Humidity greatly affects health $[7,8]$ and changes in extreme humidity lead to new disease symptoms [9]. Maintaining humidity in the cabin can be done by opening the windows while driving [10]. However, in extreme weather such as summer, connecting cabin space with environment will add excessive load to air conditioning system. On the other hand, if the humidity is too low it can cause dehydration and endanger driving safety due to driving errors [11]. Another method is to put phase change material (PCM) to control humidity and temperature in the car, but it works passively [12]. Temperature-humidity- air circulation speed is interrelated air property [13,14]. The speed of air circulation in vehicle air conditioners is generally controlled manually via a knob on the dashboard, except in modern cars equipped with sophisticated sensors. Manual controls cannot provide good thermal comfort, as airspeed reset is based solely on feedback from the passenger or driver. Therefore, air speed control in an AC system also needs to be developed.

Increasing passenger comfort in the cabin by maintaining temperature has been discussed extensively, both while the vehicle is running and when the vehicle is from a parking location $[2,4,12,13,15]$. However, the discussion on the integration of temperaturehumidity-air speed control systems based on effective human comfort is still very limited, except at the simulation stage [16-18]. Therefore, this study aims to develop a specific air conditioning control system used in vehicles to adjust temperature-humidity-air speed based on effective human comfort $\left(22{ }^{\circ} \mathrm{C} ; 40 \%\right.$ to $60 \%$ of relative humidity, $\left.\mathrm{RH}\right)$. The lab-scale prototype is tested in a simulation room, conditioned to resemble real environmental conditions. Furthermore, the room temperature was measured using a thermometer, humidity was evaluated by humidity meter, and the airflow meter was applied to estimate airflow.

\section{METHOD}

\subsection{System Description}

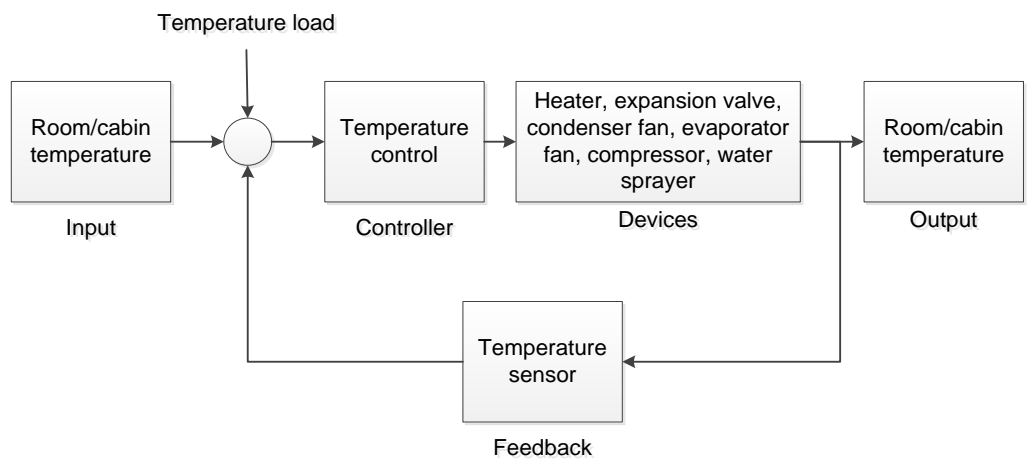

Fig. 1: The block diagram of temperature control.

The system developed is presented in Fig. 1 and Fig. 2. This system has five main blocks including the input, controller, devices, feedback, and output. Temperature control uses a closed loops system, and the feedback mechanism uses a sensor. The prototype has five components, encompassing the heater, condenser fan, evaporator fan, expansion valve, and compressor. The confounding factor of temperature control is the heat load from the 
outside. The humidity control system consists of a heater, water sprayer and humidity sensor to provide feedback.

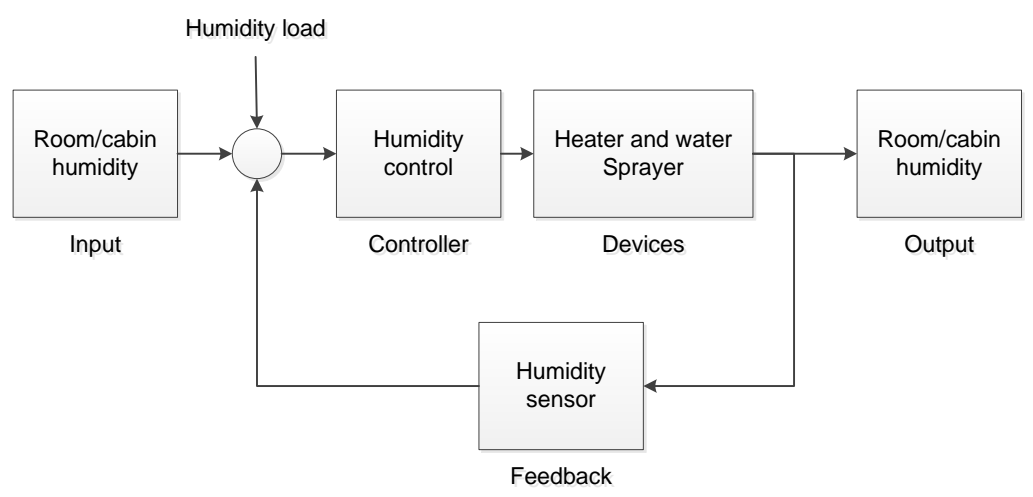

Fig. 2: The block diagram of humidity control.

\subsection{Experiment Set-up}

Figure 3 shows the experimental set-up which includes the electronic control module (1), evaporator (2), compressor (3), condenser (4), and expansion valve (5). The specifications of each equipment are shown in Table 1. The electronic control module (ECM) consists of a microcontroller, relay, and electronic circuits that are programmed based on the desired needs. The ECM works based on input from temperature and humidity sensors, and produces output to the water sprayer, condenser fan, evaporator fan, heater, and compressor. The performance mechanism of this air conditioning system follows the process shown in Fig. 4. This figure shows a psychometric diagram used to explain the conditions of the cabin space. When the cabin room has a high temperature and humidity (at point 1), the AC system will regulate temperature and humidity in a condition of thermal comfort (point 3). Process from point 1 to point 3 is a process of dehumidifying ( 1 to 2 ) and cooling (2 to 3 ). When a vehicle suddenly passes a highly cold temperatures area, the AC system will turn on the heater $(\mathrm{R})$ to increase the temperature. Likewise, when a vehicle suddenly passes through an immensely low humidity area, the AC system turns on the water sprayer which will spray water (in the form of fog) to increase the humidity in order to achieve thermal comfort conditions.

Table 1: Specifications of the tools used in the study

\begin{tabular}{|c|c|c|}
\hline No & Parts & Specification \\
\hline 1. & Evaporator & Evaporator Unit A3 Toyota; DENSO \\
\hline 2. & Compressor & $\begin{array}{l}\text { Type SD505 - SD } 505 \text { - Universal Model Sanden, piston type, driven } \\
\text { by a } 220 \text {-volt AC motor with a power of } 2 \text { HP. }\end{array}$ \\
\hline 3. & Expansion valve & TEV type (thermo expansion valve) \\
\hline 4. & Temperature sensor & $\begin{array}{l}\text { Sensor type DS18B20; Wrapped in stainless steel pipe; Dimensions } 6 \mathrm{x} \\
50 \mathrm{~mm} \text {; Cable length } 100 \mathrm{~cm} \text {; Power supply } 3-5.5 \mathrm{~V} \text {; Temperature range } \\
-55 \text { to }+125 \mathrm{C} \text {; Analog type }\end{array}$ \\
\hline 5. & Humidity sensor & $\begin{array}{l}\text { Dimension: } 28.2 \text { x } 13.1 \text { x } 10 \mathrm{~mm} \text {; Weight: } 6 \mathrm{~g} \text {; Working voltage: } 3 \mathrm{~V} \sim \\
\text { 5.5V; Output signal: digital signal; Temperature measurement range: - } \\
40^{\circ} \mathrm{C} \text { to } 80 \mathrm{C} \text {; Accuracy: } 0.5^{\circ} \mathrm{C} \text {; Humidity range: } 0 \sim 100 \% \text {; } \mathrm{RH} \\
\text { Accuracy: } 2 \%\end{array}$ \\
\hline 6. & Heater & 12 volts $300 \mathrm{~W}$ with coil type heating element \\
\hline 7. & Simulation environment & Dimension: $1.5 \times 1.5 \times 3 \mathrm{~m}$ \\
\hline
\end{tabular}




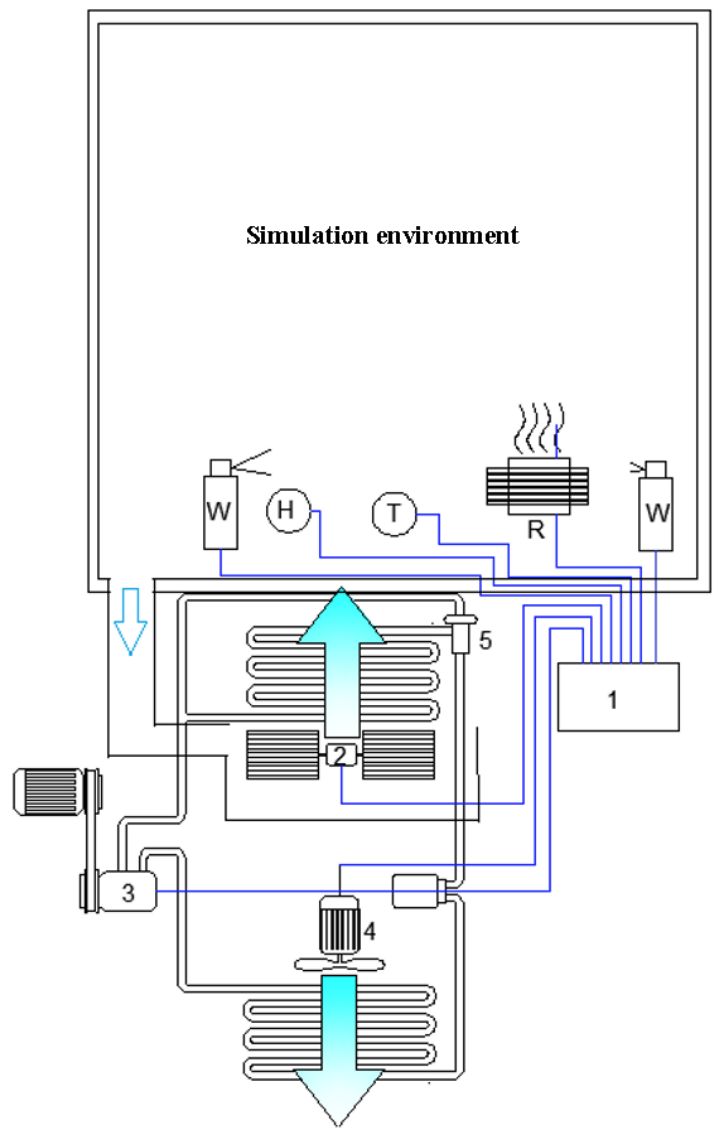

Fig. 3: Set up experiment: 1-electronic control module (ECM); 2-evaporator; 3-compressor; 4-condenser; 5-expansion valve; T-temperature sensor; H-humidity sensor; W-water sprayer; and R-heater.

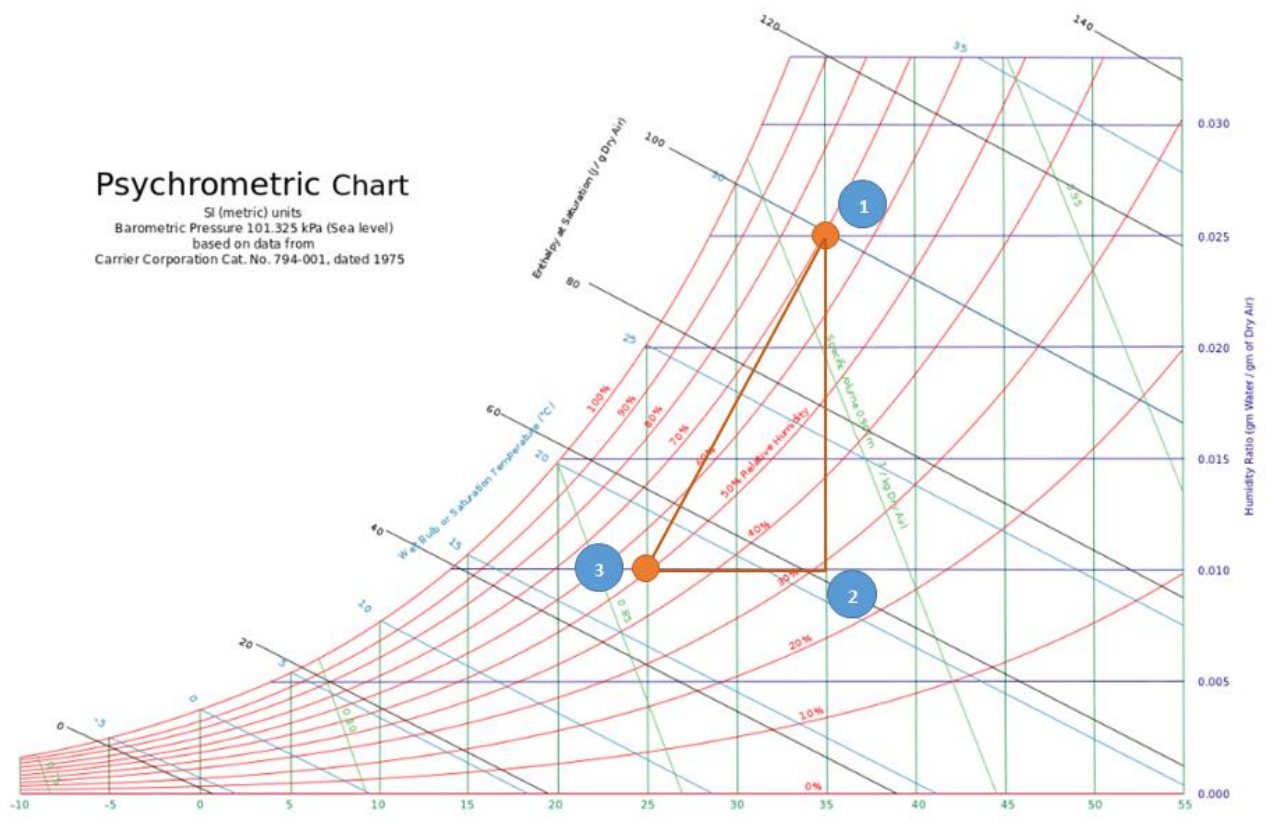

Fig. 4: Psychometric chart of AC system.

Installation of heating sensors, water spray, temperature and humidity sensors are paired adjacent to the evaporator. The ECM input includes temperature and humidity 
sensors, while the evaporator is mounted in series against the condenser and compressor. This prototype was tested during hot climates with a location in Indonesia which has a longitude position of -7.520639969601074 and latitude 110.22739445901612.

\subsection{Logic Rule of Control System}

The control system has two subsystems to control temperature and humidity of cabin air as shown in Fig. 5 and Fig. 6. The logic rule of temperature control has a working structure as follows. If the temperature is below $16^{\circ} \mathrm{C}$, the programming statement is set to turn on the heater $(\mathrm{R})$ and turn off the air conditioner but the evaporator fan is on (P1). The length of time the heater runs depends on the high and low temperature of the cabin space, so if the temperature of the cabin space is very low, it takes a longer heater lifetime to achieve thermal comfort. If the temperature of the cabin space is in the range of 17 to $20^{\circ} \mathrm{C}$, then the statement program is set to activate the AC compressor and heater with the evaporator fan at very low speed (P2). The statement program is set to turn on the evaporator fan in a very low position speed to reach a range of 21 to $24^{\circ} \mathrm{C}(\mathrm{P} 3)$ and so on according to Fig. 5.

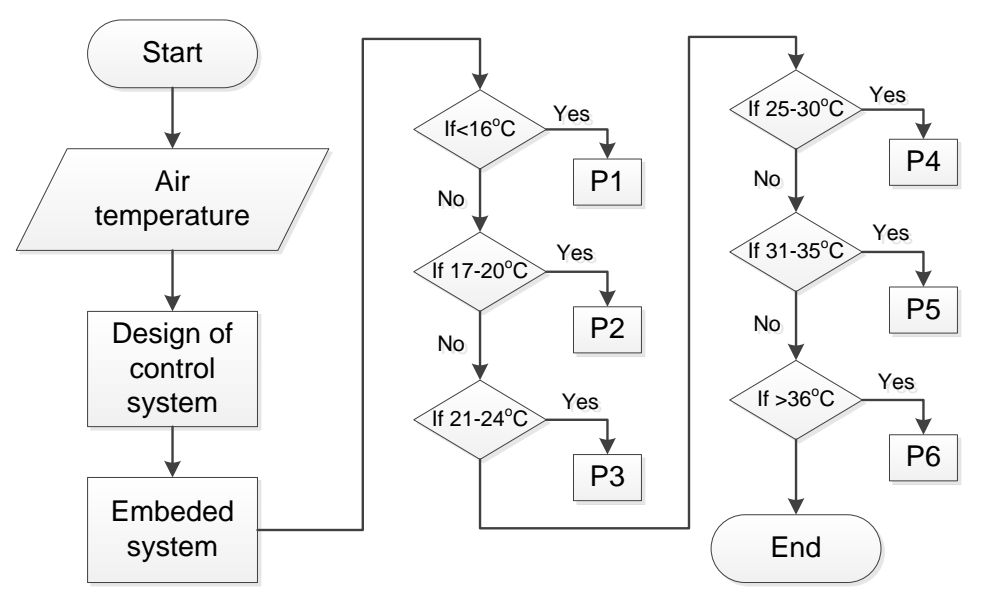

Fig. 5: Logic rule of temperature control system.

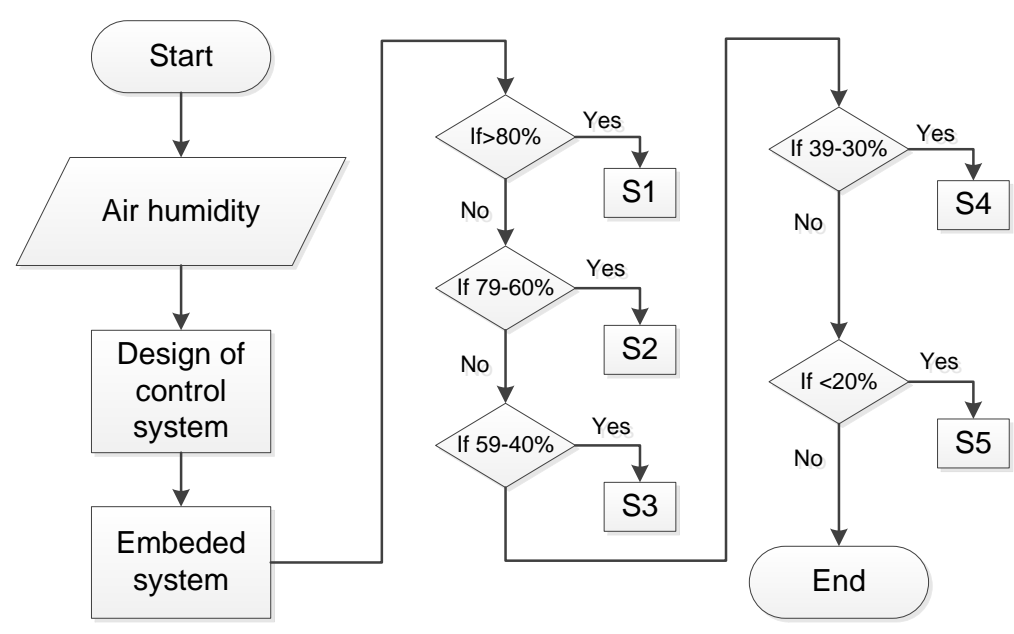

Fig. 6: Logic rule of humidity control system.

The cabin temperature is set at 25 to $30^{\circ} \mathrm{C}$, where the programming statement turns on evaporator fan to medium speed position, condenser, and expansion valve are in position 2 (P2). Furthermore, a cabin temperature of 31 to $35^{\circ} \mathrm{C}$ requires the statement program to turn on the evaporator fan to high speed, while the condenser fan and expansion valve are 
in position $3(\mathrm{P} 3)$. In addition, cabin temperatures above $36{ }^{\circ} \mathrm{C}$ require the statement program to turn on a maximum high evaporator fan, while the condenser and expansion valve are in position 4 (P4). Table 2 shows the various temperature control system statements. The condenser fan, compressor and magnetic coupling are connected in one line, so that if the magnetic coupling is on, condenser fan, the compressor will start. Likewise, if the magnetic coupling turns off, the condenser fan, the compressor will shut off.

Table 2: Statement of the air temperature control system

\begin{tabular}{|c|c|c|}
\hline No & Position & Functioning system \\
\hline 1. & P1 & $\begin{array}{l}\text { - Heater on } \\
\text { - Evaporator fan off } \\
\text { - Compressor off }\end{array}$ \\
\hline 2. & $\mathrm{P} 2$ & $\begin{array}{l}\text { - Heater on } \\
\text { - Evaporator fan on (min. low speed) } \\
\text { - Compressor on }\end{array}$ \\
\hline 3. & P3 & $\begin{array}{l}\text { - Heater off } \\
\text { - Evaporator fan on (low speed) } \\
\text { - Compressor on }\end{array}$ \\
\hline 4. & P4 & $\begin{array}{l}\text { - Heater off } \\
\text { - Evaporator fan on (medium speed) } \\
\text { - Compressor on }\end{array}$ \\
\hline 5. & P5 & $\begin{array}{l}\text { - Heater off } \\
\text { - Evaporator fan on (hight speed) } \\
\text { - Compressor on }\end{array}$ \\
\hline 6. & P6 & $\begin{array}{l}\text { - Heater off } \\
\text { - Evaporator fan on (max. high speed) } \\
\text { - Compressor on }\end{array}$ \\
\hline
\end{tabular}

The humidity control system algorithm works with the following conditions. If the humidity in cabin space is more than $80 \%$, the statement program is set to turn on the air conditioning system which aims to remove moisture in cabin space. If the air reads very dry (below 39\%), water spray is activated to increase humidity. Meanwhile, if the humidity reads at 40 to $60 \%$, the sprinkler and heater are turned off. Table 3 shows the humidity control system statements and algorithms.

Table 3: Statement of the air humidity control system

\begin{tabular}{ccc}
\hline No & Position & Functioning system \\
\hline 1. & S1 & Heater on \\
2. & S2 & Heater on \\
3. & S3 & - \\
4. & S4 & Sprayer in position 1 \\
5. & S5 & Sprayer in position 2 \\
\hline
\end{tabular}

Air temperature and humidity were measured in the cabin space, the lowest and highest values observed were $17{ }^{\circ} \mathrm{C}$ and $31{ }^{\circ} \mathrm{C}$, respectively. Meanwhile, the lowest and highest humidity data were obtained in the range of $20 \%$ and $84 \%$. Data is collected at 380 meters above sea level. Temperature, air velocity, and humidity data were collected using a digital thermometer, airflow meter and humidity meter, respectively. 


\section{RESULTS AND DISCUSSION}

\subsection{Wiring Diagram of Developed Prototype}

Integrated control system for cabin room comfort has interconnected parts. The circuit which includes input, controller, actuator, output and feedback is characterized by a sequential working system. The LM 35 sensor is a temperature sensitive device that is known to produce analog signals. Therefore, changes in temperature of simulation room can be detected based on modification of the resistance. The DHT11 sensor is able to detect ambient air humidity by measuring amount of water vapor in simulation room. Figure 7 shows the wiring diagram made.

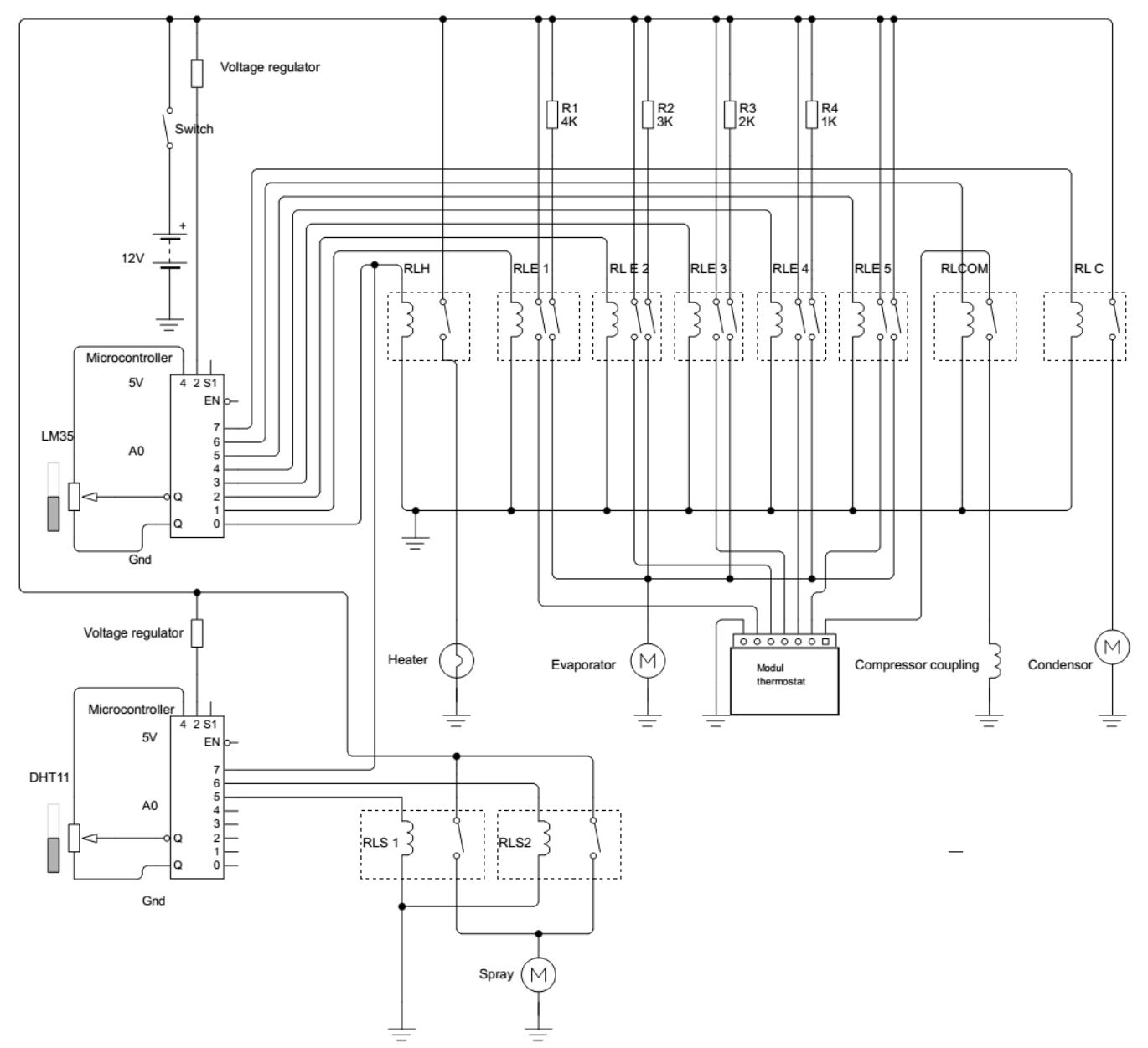

Fig. 7: Wiring diagram of the controller system.

\subsection{Air Speed, Temperature, and Humidity Measurement}

The automatic integration control system for room comfort was set at $22{ }^{\circ} \mathrm{C}$, based on the effective comfort for humans [19], while the simulation room temperature was obtained from $31^{\circ} \mathrm{C}$. The temperature at the $21^{\text {st }}$ minute has reached a precise setting, and period of decline is affected by thermal load. Furthermore, airspeed is modified based on temperature previously achieved, as $7.8 \mathrm{~m} / \mathrm{s}$ produced by evaporator fan is generated at $31^{\circ} \mathrm{C}$. Based on the evaluation, an automatic decline to $7 \mathrm{~m} / \mathrm{s}$ was reported at $30^{\circ} \mathrm{C}$, and $6.5 \mathrm{~m} / \mathrm{s}$ was achieved after reaching $22{ }^{\circ} \mathrm{C}$. The controller system subsequently maintains temperature in the range of 21 to $23{ }^{\circ} \mathrm{C}$, and the results in Fig. 8 show comparison between automatic and manual techniques. 


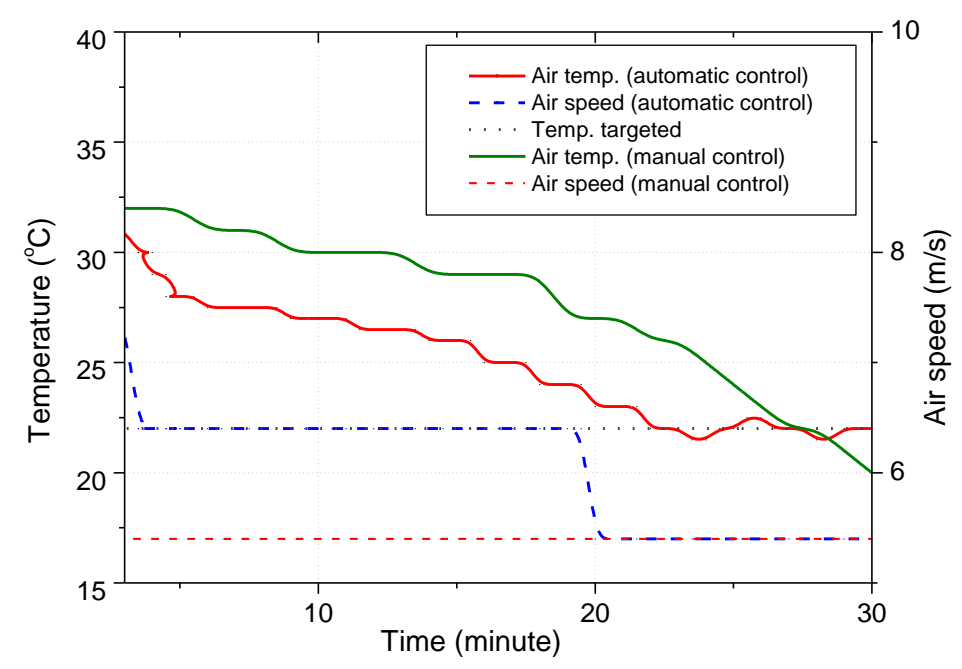

Fig. 8: Temperature and airspeed at the highest temperature position.

Manually controlled air temperatures have several conditions, and $5.5 \mathrm{~m} / \mathrm{s}$ is used as speed position of evaporator fan. Furthermore, a decline in temperature requires a longer time compared to an automatic control system, as only $18{ }^{\circ} \mathrm{C}$ is reached within 30 minutes. This condition possibly occurs due to the presence of constant evaporator fan speed, which does not increase automatically, hence the need to achieve the addition of automatic comfort temperature. In addition, it was not possible for the manual control system to reach an effective position for humans $\left(22^{\circ} \mathrm{C}\right)$ in the $30^{\text {th }}$ minute.

Data were collected at $17^{\circ} \mathrm{C}$, and under this condition, the controller turns on the heater. This subsequently generates heat in the simulation enviroment, while the airspeed assists in spreading the warm air emitted. Furthermore, $20^{\circ} \mathrm{C}$ was reached on the $20^{\text {th }}$ minute, and then the control system turns off the heater, subsequently circulating the heat in order to maintain $22{ }^{\circ} \mathrm{C}$. Also, the system works to achieve an effective temperature for humans, and Fig. 9 shows the simulation environment characteristics with the heater. The manually controlled systems require a speed of $5.5 \mathrm{~m} / \mathrm{s}$ and only $18{ }^{\circ} \mathrm{C}$ is reached at the $30^{\text {th }}$ minute. The temperature increase process tends to be slower because the manual controls are not integrated with the heater system. The performance characteristics of the temperature control system are successful in working in the range of $21^{\circ} \mathrm{C}$ to $23{ }^{\circ} \mathrm{C}$ which is closer to human thermal comfort (effective temperature setting).

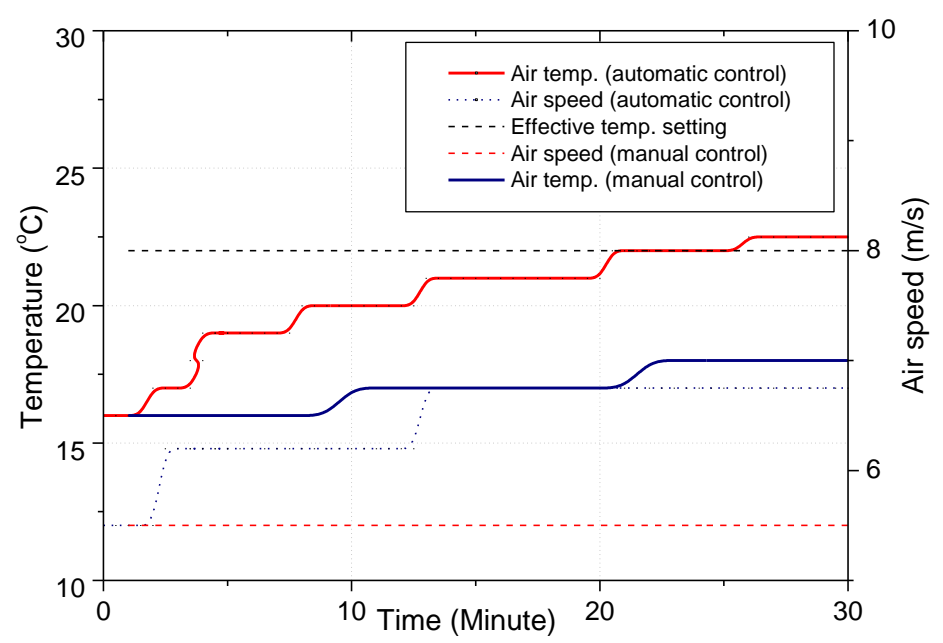

Fig. 9: Temperature and airspeed at the lowest temperature position. 
Air humidity data is obtained from simulation chamber at the highest condition of $90 \%$, characterized by relatively large (wet) water vapor content. Furthermore, the automatic control system turns on the heater to $60 \%$ position and aimed at achieving the simulation room dry out. The heated air with water vapor content is further removed from the room with a removal system, while the humidity decreases. Meanwhile, the automatic system has the ability to maintain the humidity conditions at $40 \%$ to $60 \%$. Figure 10 shows the control system characteristics. The regulation data for air humidity in a manual system is obtained at around $90 \%$, in order to turn on the heater. However, a slight decline was observed at $89 \%$ on the $30^{\text {th }}$ minute, resulting from the opened ventilation.

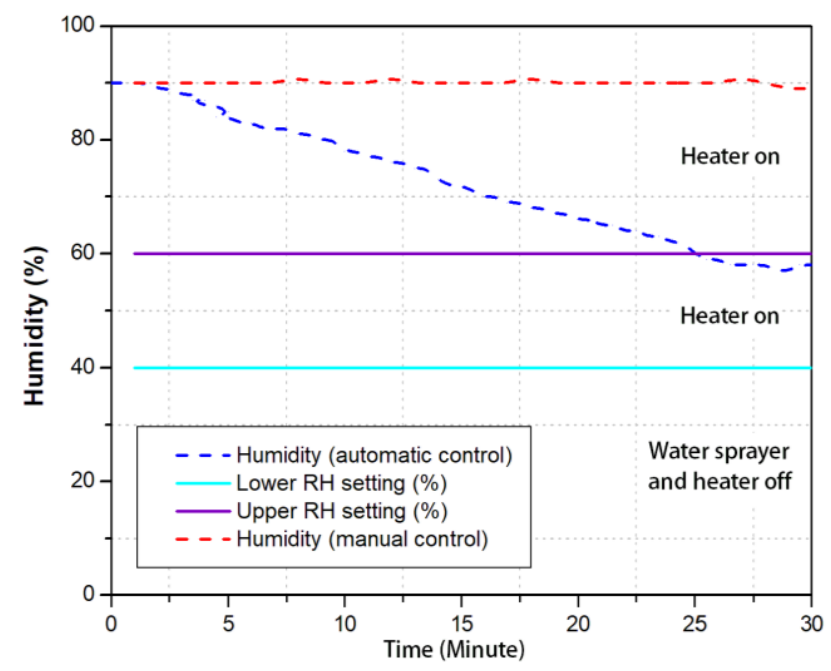

Fig. 10: Air humidity at the highest position.

The air humidity is obtained at the lowest position (dry) in simulation room, using a humidity tester. Therefore, the speed of achieving this condition is increased by exposing the environment to an initial draining process. This involves the removal of hot air, and new data is collected after reaching the least position (dry). The automatic control systems operated is then commenced at the initial lowest humidity level of $20 \%$, where the water sprayer is turned on, and consequently emitting moist mist. Therefore, the humidity slowly increases to $40 \%$, where the sprayer is turned off. This controller system maintains ideal humidity conditions between $40 \%$ to $60 \%$, and Fig. 11 shows test results from the lowest humidity position.

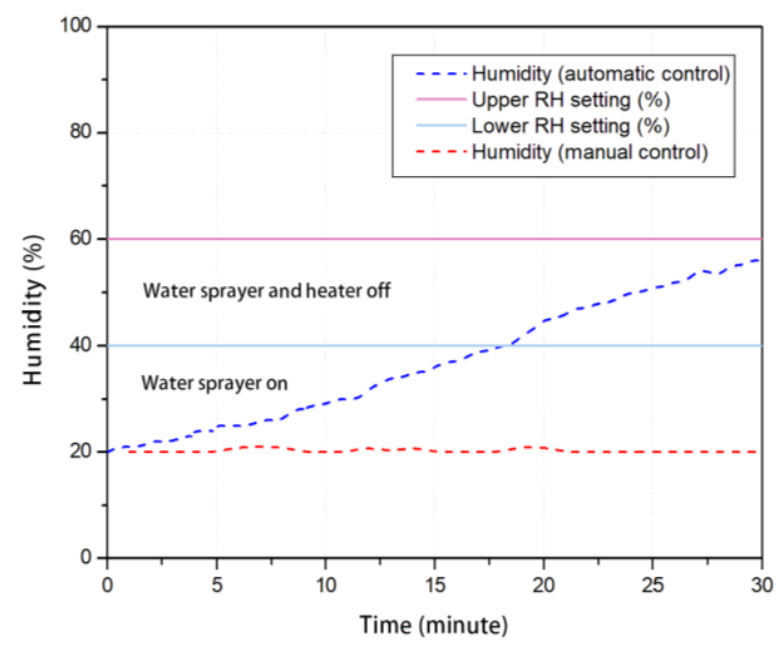

Fig. 11: Air humidity at the lowest position. 
Furthermore, the air humidity in a manual system is obtained data at $20 \%$ because of the inability to turn on the water sprayer. Hence, there is a high difference between this application and an automatic system with the capacity to reduce and maintain effective humidity for humans. The script programming of the temperature control system is shown in Appendix 1.

\section{CONCLUSION}

Comprehensive conclusion was made based on the test results, which include:

- In the aspect of room temperature, the control system data retrieved was in the highest position (hot), and the automatic control system was able to reduce the room temperature from $31{ }^{\circ} \mathrm{C}$ to range from $21{ }^{\circ} \mathrm{C}$ to $23{ }^{\circ} \mathrm{C}$ in 21 minutes. This prototype works according to settings in effective temperature area to attain human comfort. However, the manual controllers only reach $27{ }^{\circ} \mathrm{C}$ in 21 minute, hence longer time is required to cool the room, and it is also difficult to achieve optimal temperatures for passengers. Room control systems are tested from the lowest temperature position (cold), where automatic unit turns on heater in the simulation room. Therefore, $17^{\circ} \mathrm{C}$ is raised to the settings in range of $21^{\circ} \mathrm{C}$ to $23{ }^{\circ} \mathrm{C}$, and the speed temperature fluctuation is influenced by room volume and heater/AC control capacity. Furthermore, effective temperatures are not reached in manual control systems because of the inability to warm up the room.

- Based on the data retrieved, the humidity control system was at the highest position (wet) at $90 \%$. Therefore, the automatic unit turns on the heater system to promote air vapor dryness and subsequent removal from the simulation room. This unit reduces humidity to a range of $40 \%$ to $60 \%$ (effective humidity for human comfort). Meanwhile, the manual system is unable to cause a decline to the effective value for passengers due to the non-integration with the heater and sprayer.

- Based on the data retrieved, humidity control system was in the least position (dry), working at $20 \%$. Furthermore, automatic unit turns on water sprayer, subsequently leading to higher humidity up to the range of $40 \%$ to $60 \%$. Also, it is able to work according to the setting of humans effective comfort, both in terms of temperature and humidity regulation. However, this condition is not attainable by the manual controllers. This is a model study, and the automatic system created shows better work capacity than the manual, hence greater potential for application in the cabin rooms of real vehicles. The fluctuation rate of temperature and humidity is set based on the regulation capacity of the heater, air conditioner, and room volume.

\section{REFERENCES}

[1] Kristanto D, Leephakpreeda T. (2017) Sensitivity analysis of energy conversion for effective energy consumption, thermal comfort, and air quality within car cabin. Energy Procedia, 138: 552-557. https://doi.org/10.1016/j.egypro.2017.10.158

[2] Danca P, Nastase I, Bode F, Croitoru C, Dogeanu A, Meslem A. (2019) Evaluation of the thermal comfort for its occupants inside a vehicle during summer. IOP Conference Series: Materials Science and Engineering, 595(1). https://doi.org/10.1088/1757899X/595/1/012027

[3] Setiyo M, Widodo N, Purnomo BC, Munahar S, Rahmawan MA. (2019) Harvesting cooling effect on LPG-fueled vehicles for mini cooler : A lab-scale investigation. Indonesian Journal of Science \& Technology, 4(1): 39-47. https://doi.org/10.17509/ijost.v4i1.12834 
[4] Ravindra K, Agarwal N, Mor S. (2020) Assessment of thermal comfort parameters in various car models and mitigation strategies for extreme heat-health risks in the tropical climate. $\begin{array}{llll}\text { Journal of Environmental } & 110655 .\end{array}$ https://doi.org/10.1016/j.jenvman.2020.110655

[5] Zhou X, Lai D, Chen, Q. (2019) Experimental investigation of thermal comfort in a passenger car under driving conditions. Building and Environment, 149: 109-119. https://doi.org/10.1016/j.buildenv.2018.12.022

[6] Shahzad S, Brennan J, Theodossopoulos D, Hughes B, Calautit JK. (2016) The accuracy of thermal comfort zone, ASHRAE Standard 55-2013. CIBSE Technical Symposium. http://hdl.handle.net/10545/620577

[7] Zhai Y, Zhang Y, Zhang H, Pasut W, Arens E. (2015) Human comfort and perceived air quality in warm and humid environments with ceiling fans. Building and Environment, 90: 178-185. https://doi.org/10.1016/j.buildenv.2015.04.003

[8] Toftum J, Anette SJ, Fanger PO. (1998) Upper limits for indoor air humidity to avoid uncomfortably humid skin. Energy and Buildings, 28: 1-13. https://doi.org/10.1016/S03787788(97)00017-0

[9] Javadinejad S, Dara R, Jafary F. (2020) Potential impact of climate change on temperature and humidity related human health effects during extreme condition. Safety in Extreme Environments, 2: 189-195. https://doi.org/10.1007/s42797-020-00021-x

[10] Gładyszewska-Fiedoruk K, Teleszewski TJ. (2020) Modeling of humidity in passenger cars equipped with mechanical ventilation. Energies, 13(11). https://doi.org/10.3390/en13112987

[11] Watson P, Whale A, Mears SA, Reyner LA, Maughan RJ. (2015) Mild hypohydration increases the frequency of driver errors during a prolonged, monotonous driving task. Physiology and Behavior, 147: 313-318. https://doi.org/10.1016/j.physbeh.2015.04.028

[12] Afzal A, Saleel CA, Badruddin IA, Khan TMY, Kamangar S, Mallick Z, Samuel OD, Soudagar MEM. (2020) Human thermal comfort in passenger vehicles using an organic phase change material- an experimental investigation, neural network modelling, and optimization. Building and Environment, 180: 107012. https://doi.org/10.1016/j.buildenv.2020.107012

[13] Li CL, Zhang X, Chung SL. (2012) Temperature and humidity control inside an automobile during heating period. Journal of the Chinese Institute of Engineers, Transactions of the Chinese Institute of Engineers, Series A, 35(6): 641-654. https://doi.org/10.1080/02533839.2012.701853

[14] Khatoon S, Kim MH. (2020) Thermal comfort in the passenger compartment using a 3-D numerical analysis and comparison with Fanger's comfort models. Energies, 13(3). https://doi.org/10.3390/en13030690

[15] Purnomo BC, Setiawan IC, Nugroho HA. (2020) Study on cooling system for parked cars using mini air cooler and exhaust fan. Automotive Experiences, 3(2): 81-88. https://doi.org/10.31603/ae.v3i2.3801

[16] Wang Y, Gao Q, Zhang T, Wang G, Jiang Z, Li Y. (2017) Advances in integrated vehicle thermal management and numerical simulation. Energies, 10(10). https://doi.org/10.3390/en10101636

[17] Brusey J, Hintea D, Gaura E, Beloe N. (2018) Reinforcement learning-based thermal comfort control for vehicle cabins. Mechatronics, 50: 413-421. https://doi.org/10.1016/j.mechatronics.2017.04.010

[18] Warey A, Kaushik S, Khalighi B, Cruse M, Venkatesan G. (2020) Data-driven prediction of vehicle cabin thermal comfort: using machine learning and high-fidelity simulation results. International Journal of Heat and Mass Transfer, 148: 119083. https://doi.org/10.1016/j.ijheatmasstransfer.2019.119083

[19] Buonocore C, De Vecchi R, Scalco V, Lamberts R. (2020) Thermal preference and comfort assessment in air-conditioned and naturally-ventilated university classrooms under hot and humid conditions in Brazil. Energy and Buildings, 211: 109783. https://doi.org/10.1016/j.enbuild.2020.109783 


\section{Appendix 1: Script Programming}

const int TemperatureLM35 = A0;

float temperature, data;

const int relay $1=2$;

const int relay $2=3$;

const int relay $3=4$;

const int relay $4=5$;

const int relay $5=6$;

const int relay $6=7$;

void setup() \{

Serial.begin(9600);

pinMode(TemperatureLM35, INPUT);

pinMode(relay1, OUTPUT);

pinMode(relay2, OUTPUT);

pinMode(relay3, OUTPUT);

pinMode(relay4, OUTPUT);

pinMode(relay5, OUTPUT);

pinMode(relay6, OUTPUT);

\}

void $\operatorname{loop}()$ \{

data $=$ analogRead (TemperatureLM35);

temperature $=$ data $/ 2.0408$;

Serial.print("temperature: ");

Serial.print(temperature);

Serial.println();

delay(1000);

if (temperature $<=16$ ) //heater on

\{

digitalWrite(relay1, HIGH);

digitalWrite(relay2, LOW);

digitalWrite(relay3, LOW);

digitalWrite(relay4, LOW);

digitalWrite(relay5, LOW);

digitalWrite(relay6, LOW);

\}

else if ( temperature $<=20$ )// very low speed

\{

digitalWrite(relay1, HIGH);

digitalWrite(relay2, HIGH);

digitalWrite(relay3, LOW);

digitalWrite(relay4, LOW);

digitalWrite(relay5, LOW);

digitalWrite(relay6, LOW);

\}

else if( temperature $<=24) / /$ low speed

\{

digitalWrite(relay1, LOW);

digitalWrite(relay2, LOW);

digitalWrite(relay3, HIGH);

digitalWrite(relay4, LOW);

digitalWrite(relay5, LOW);

digitalWrite(relay6, LOW);

\}

else if( temperature $<=30$ )// medium speed

\{

digitalWrite(relay1, LOW);

digitalWrite(relay2, LOW);

digitalWrite(relay3, LOW); 


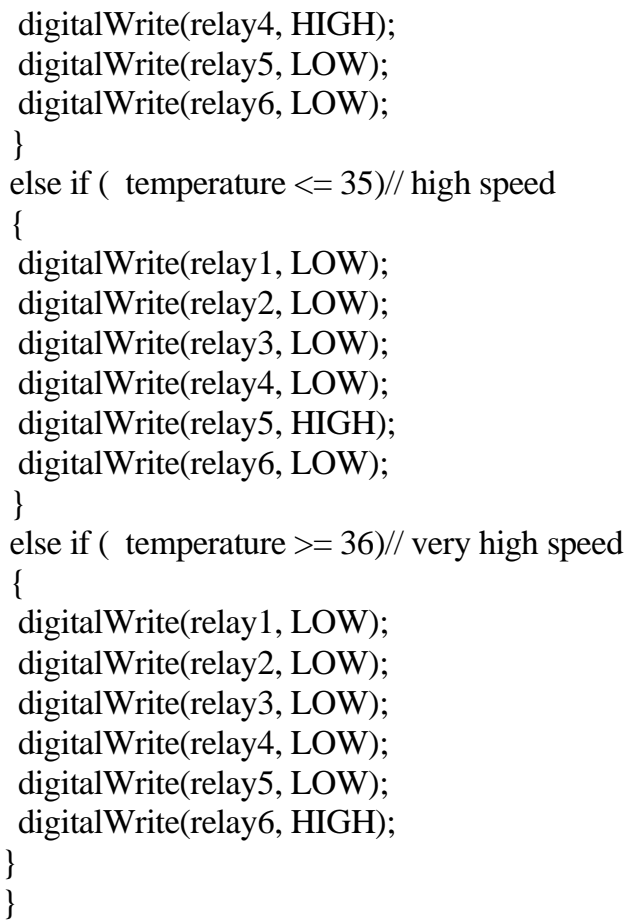




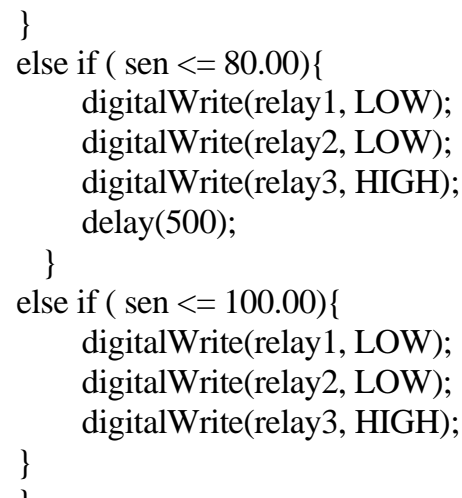

